\title{
Effect analysis of environmental factors on the children's Amazon community neuropsychomotor development
}

Open acess

${ }^{1}$ Universidade do Estado do Pará (UEPA) - Belém (PA), Brasil. 2Universidade Federal do Pará (UFPA) - Belém (PA), Brasil

\section{Corresponding author:}

lucienypontes@hotmail.com

Manuscript received: April 2018

Manuscript accepted: October 2018

Version of record online: November 2018
Ana Paula Pureza Pantoja1, Givago da Silva Souza², Erica Feio Carneiro Nunes ${ }^{1}$, Lucieny da Silva Pontes ${ }^{1}$

\begin{abstract}
Introduction: The early years of a child's life are marked by a significant development, as well as high sensitivity to environmental influences such as poverty, housing, quality and family structure. Thus, the identification of environmental risk factors and delayed neurodevelopment, coupled with early intervention, are essential for an healthy development.
\end{abstract}

Objective: To analyze the effect of environmental factors on the neuropsychomotor development of children in the Amazon community.

Methods: This is a quantitative and qualitative study of analytical and cross-sectional approach with 50 children between 24 and 36 months of age, of both sexes, living in an Amazonian community. Two types of the socioeconomic-environmental questionnaire were used; a) Infant/Toddler (IT) HOME Inventory to analyze the quality of the family environment; b) the Denver Screening Test II for screening neurodevelopment. Also, a descriptive analysis was performed using a calculation of means and standard deviations

Results: The study found that a significant majority of the children had normal neuropsychomotor development; however, children classified as delayed, the more significant impact variable in the development was the quality of the family environment, which in turn was influenced by the lower economic class, lack of water treatment, lack of electricity and external toilet.

Conclusion: Environmental factors were not significant on the neuropsychomotor development of the local children of the Amazon community.

Keywords: neuropsychomotor development, environment, family relationships, social vulnerability. 


\section{INTRODUCTION}

The Amazon is the region with the highest biodiversity and the largest hydrographic basin on the planet, formed by a variety of ecosystems, from high and dense forests to floodplains, igapós and boreholes (types of amazonian ecosystems). Along the bank of its rivers, lives a population known as riverside ${ }^{1}$. Riverside communities, traditional people living around the river, are marked by an evident degree of isolation and social exclusion, as well as precarious investments in public policies since geographic isolation becomes a barrier for these families to have access and equal opportunities in the economic, education and health space ${ }^{\mathrm{s} 2}$.

In developing countries, about 219 million children under 5 years of age do not reach their development potential. Among the main factors, are malnutrition, poor conditions, neuropsychomotor stimulation and inadequate language ${ }^{3}$.

Among the factors that influence in the development of children, a dynamic interaction of biological and environmental conditions ${ }^{4}$ is admitted. Regarding the environmental factors, the physical space where the child lives, family structure and dynamics, verbal stimulation, emotional involvement, socioeconomic conditions, among others, are mentioned ${ }^{5}$.

The family context is a great mediator of the models, patterns, and social influences, being one of the first socialization environments with which the child maintains contact. Thus, the quality of the affective bonds between parents and children, stable conditions of life - both socioeconomic and psychosocial - and quality and variability of stimuli are essential factors for child development ${ }^{6,7}$.

The unfavorable economic condition is a significant risk factor for children's health and development, with a wide range of consequences, such as behavioral problems, deficits in language, attention, memory and executive functions in childhood and throughout life. These consequences are not only related to the low purchasing power, but also to the exposures associated with poverty such as the precarious domestic infrastructure, living in neighborhoods with high levels of violence, family agglomeration, and air pollution ${ }^{8}$.

The first three years of a child's life are marked by rapid and essential development, as well as a high sensitivity to environmental influences. In this way, the identification of environmental risk factors, disabilities and developmental delays in the first years of the child's life, together with early intervention, provide a better chance of reaching the full capacity of child development ${ }^{9}$.

According to the United Nations Development Program10, the municipality of Igarapé-Miri/Pará, Brazil is among the worst in the Municipal Human Development Index (0.547) in the year 2010, suggesting that its inhabitants have few social development opportunities, being able to be in disadvantages concerning their participation and social inclusion. Thus, this study aimed to analyze the effects of environmental factors on the neuropsychomotor development of riverine children in the Amazonian community Panacauera, Igarapé-Miri/Pará.

\section{METHODS}

This is a cross-sectional and analytical qualitative and quantitative study with children between 24 and 36 months of age, living with their families in the Amazonian community of Panacauera, located in the fluvial rural area of the municipality of Igarapé-Miri/Pará, Brazil. The research was approved by the Research Ethics Committee of the State University of Pará (UEPA), under the number 622,947 .

The Municipality of Igarapé-Miri is located in the mesoregion of northeastern Pará, a micro-region of Baixo Tocantins, 78 kilometers from the state capital, with an area of the territorial unit equivalent to $1,996,843$ kilometers ${ }^{11}$. The Panacauera community is located in the region of the islands of Igarapé-Mirí, and the only access is using fluvial transport.

The population of children between 24 and 36 months of the Panacauera community at the time of survey was approximately 110 children. Thus, the sample value was calculated through the sample calculation, with error percentage of $10 \%$, due to the conditions and aspects involved in data collection such as reduced collection time. Difficulty in transportation and access to residences. In this way, the sample totaled 50 children, of whom there were no losses.

As inclusion criteria, children aged between 24 and 36 months, of both sexes, born with gestational age $>$ 37 weeks and weight $>2500 \mathrm{~g}$, eutrophic, residents of the Panacauera community, were selected, who agreed to sign the Free and Clarified Consent.

A socioeconomic-environmental questionnaire was prepared by the researchers, containing information about the mother and/or responsible, family history, information about the father, living conditions, and environment. The socioeconomic profile was defined according to the Brazilian Association of Research Companies ${ }^{12}$, which is based on consumption power (material goods and services) added to the head of household's education, each item having its score value, with a minimum score of zero points and the maximum of 46 points, stratifying families in class A, B, C, D, and E, in which class A represents the best economic and social situation, followed by classes $\mathrm{B}$, $\mathrm{C}, \mathrm{D}$ considered intermediate and class $\mathrm{E}$, representing the worst economic situation.

We used the Home Observation for Measurement of the Environment (HOME) Inventory to measure the quality and quantity of stimulation and support available to a child in the home environment. There are currently four versions of the inventory that cover the ages of 0 to 3,3 to 6 years, 6 to 10 years and a version for teens from 10 to 14 years. The four versions share some common dimensions although each version also contains items and dimensions considered to be particularly relevant for the period of development to which they refer ${ }^{13,14}$.

The version used was Infant/ Toddler (IT) HOME Inventory, for children between 0 -3 years of age, composed of 45 items, divided into six subscales. (i) Caregiver Responsiveness - related to affective verbalizations and interactions. (ii) Acceptance of the child - items related to behavioral and disciplinary control practices. (iii) 
Organization of the environment - characteristics of the routine organization of the child inside and outside the home. (iv) Materials for learning - evaluation of the toys available to the child, as well as their developmental suitability. (v) Involvement of parents - the routine of parent-child interactions, promoters of development. (vi) Variety of experience - social contact with others other than parents. The score ranks in high risk (from 0 to 25 items), medium level of risk (from 26 to 36 items) and low-risk level (from 37 to 45 items) ${ }^{13,14}$.

Moreover, for neuropsychomotor development screening, the Denver II Trial Test was used, a test composed of 125 items that are divided into four domains: social-personal, language, fine adaptive motor, and broad motor skills. The test was interpreted as normal, risk, and delay. Cases of risk were those in which the child presented an item of failure and/or two or more attention, of delay when presented two or more items of failure, regardless of the area in which the failure occurred. In other cases, the child was considered normal ${ }^{15}$.

Data collection was done at home, through an interview with the main caregiver of the child and directly with the child, in the case of the application of the specific tests. An only one trained researcher was required to apply the questionnaires and scales so that there was no bias during the evaluations.
For the descriptive analysis of the data, the calculation of the means and standard deviations was used. In the inferential statistics, Student's t-test was used to compare quantitative variables between two different groups and Tukey was adopted as posthoc for comparison of means between three or more groups. Regarding the qualitative variables, the Chi-square test and Pearson's linear correlation were used to compare the prevalence of the variables to verify the association between them. The level of significance was set at $p<0.05$. The data were stored and analyzed in the statistical program SPSS 19.0 and presented through tables.

\section{RESULTS}

The sample consisted of 50 children with a mean age of $30.67 \pm 4.23$ months, ranging from 24 to 36 months, $42 \%$ female $(\mathrm{F})$ and $58 \%$ male $(\mathrm{M})$.

During the interviews, information from the mother or responsible family history, information about the father, housing and environmental conditions and socioeconomic status were collected, characterizing the socio-environmental variables observed in Table 1. These families live mostly in the extreme poverty, with poor housing conditions, without adequate water treatment, and half of families still without electricity.

Table 1: Socio-environmental qualitative characteristics of the sample.

\begin{tabular}{|c|c|c|c|c|c|c|c|}
\hline \multirow{2}{*}{$\begin{array}{l}\text { Variable } \\
\text { Marital Status of } \\
\text { Mother }\end{array}$} & \multicolumn{5}{|c|}{ Description } & \multirow[t]{2}{*}{$x^{2}$} & \multirow[t]{2}{*}{$\mathbf{p}$} \\
\hline & Single & Married & U.free & Sep./Div. & Widow & & \\
\hline & $5(10 \%)$ & $9(18 \%)$ & $34(68 \%)$ & $1(2 \%)$ & $1(2 \%)$ & 76.4 & $<0.01$ * \\
\hline \multirow[t]{2}{*}{$\begin{array}{l}\text { Degree of } \\
\text { Motherhood }\end{array}$} & $\begin{array}{l}\text { Elementary } \\
\text { school } \\
\text { Incomplete }\end{array}$ & $\begin{array}{l}\text { High school } \\
\text { Incomplete }\end{array}$ & $\begin{array}{l}\text { High school } \\
\text { Incomplete }\end{array}$ & Others & & 20.40 & 0.01 \\
\hline & $14(28 \%)$ & $9(18 \%)$ & $9(18 \%)$ & $18(36 \%)$ & & & \\
\hline Birth Order & $\begin{array}{l}\text { Single } \\
12(24 \%)\end{array}$ & $\begin{array}{c}2^{\circ} \\
17(34 \%)\end{array}$ & $\begin{array}{c}1^{\circ} \\
9(18 \%)\end{array}$ & $\begin{array}{c}3^{\circ} \\
8(16 \%)\end{array}$ & $\begin{array}{l}\text { Other } \\
4(8 \%)\end{array}$ & 31.76 & $<0.01^{*}$ \\
\hline Father's absence & $\begin{array}{c}\text { Yes } \\
5(10.0 \%)\end{array}$ & $\begin{array}{l}\text { No } \\
44(88.0 \%)\end{array}$ & $\begin{array}{c}\text { Death } \\
1(2.0 \%)\end{array}$ & & & 67.72 & $<0.01^{*}$ \\
\hline Family structure & $\begin{array}{l}\text { Monopar. } \\
1(2.0 \%)\end{array}$ & $\begin{array}{c}\text { Monop.Exp. } \\
5(10.0 \%)\end{array}$ & $\begin{array}{c}\text { Bip. } \\
30(60.0 \%)\end{array}$ & $\begin{array}{l}\text { Bip.Exp. } \\
14(28.0 \%)\end{array}$ & & 39.76 & $<0.01^{*}$ \\
\hline Type of House & \multicolumn{2}{|c|}{ Brick } & \multicolumn{2}{|c|}{ Wood } & & 35.28 & $<0.01^{*}$ \\
\hline Water supply & \multicolumn{5}{|c|}{$\begin{array}{l}\text { Directly from the river } \\
50(100.0 \%)\end{array}$} & - & - \\
\hline Water treatment & $\begin{array}{l}\text { Filtration } \\
7(14.0 \%)\end{array}$ & $\begin{array}{c}\text { Boil } \\
4(8.0 \%)\end{array}$ & $\begin{array}{c}\text { Chlorination } \\
14(28.0 \%)\end{array}$ & $\begin{array}{c}\text { Without } \\
25(50.0 \%)\end{array}$ & & 20.88 & $<0.01^{*}$ \\
\hline Bathroom Features & \multicolumn{2}{|c|}{$\begin{array}{l}\text { Own Internal } \\
5(10.0 \%)\end{array}$} & \multicolumn{2}{|c|}{$\begin{array}{l}\text { External self } \\
45(90.0 \%)\end{array}$} & & 32.00 & $<0.01 *$ \\
\hline Electricity & \multicolumn{2}{|c|}{ Yes } & \multicolumn{2}{|c|}{ No } & & 0.00 & 1.00 \\
\hline Economic class & $\begin{array}{c}\text { B } \\
2(4.0 \%)\end{array}$ & $\begin{array}{c}C \\
5(10.0 \%)\end{array}$ & $\begin{array}{c}D \\
5(10.0 \%)\end{array}$ & $\begin{array}{c}E \\
38(76.0 \%)\end{array}$ & & 69.84 & $<0.01^{*}$ \\
\hline
\end{tabular}


The family structure is predominantly biparental, with the children having the conviviality with the father and the mother. The maternal figure is composed of mothers of little study and young people, with a mean of $23.80 \pm 5.23$ years, while the paternal age was the highest of $26.89 \pm 4.57$ years. The number of siblings of the child was $1.44 \pm 1.64$ and the number of residents in the house with the child presented an average of $5.04 \pm 2.64$ people.
Data on the quality of the family environment, according to the HOME protocol, can be verified in Table 2, showing that the discrete majority of the cited variables presented high and medium risk, especially regarding the characteristics of the routine organization of the child within and away from home, the toys available and variety of experience experienced by the child.

Table 2: Qualitative characteristics of the child for the family environment quality variables according to the HOME protocol.

\begin{tabular}{lccccc}
\hline Variable & \multicolumn{3}{c}{ Risk } & $\mathbf{x}^{\mathbf{2}}$ & $\mathbf{p}$ \\
\hline & High level & Medium Level & Low level & & \\
Responsiveness & $12(24.0 \%)$ & $18(36.0 \%)$ & $20(40.0 \%)$ & 2.08 & 0.35 \\
Acceptance & $4(8.0 \%)$ & $14(28.0 \%)$ & $32(64.0 \%)$ & 24.16 & $<\mathbf{0 . 0 1 ^ { * }}$ \\
Organization & $34(68.0 \%)$ & $9(18.0 \%)$ & $7(14.0 \%)$ & 27.16 & $<\mathbf{0 . 0 1 ^ { * }}$ \\
Material & $37(74.0 \%)$ & $6(12.0 \%)$ & $3(6.0 \%)$ & 37.24 & $<0.01^{*}$ \\
Involvement & $13(26.0 \%)$ & $22(44.0 \%)$ & $15(30.0 \%)$ & 2.68 & 0.26 \\
Variety & $2(4.0 \%)$ & $28(56.0 \%)$ & $20(40.0 \%)$ & 21.28 & $<\mathbf{0 . 0 1 ^ { * }}$ \\
Total Score & $22(44.0 \%)$ & $18(36.0 \%)$ & $10(20.0 \%)$ & 4.48 & 0.11 \\
\hline
\end{tabular}

The majority of the riverside children in the Panacauera community presented neuropsychomotor development, according to the Denver I Screening Test, normal (Table 3); however, we observed 13 children with delay, most of them in the language field.

The present study evidenced a positive relationship between the best quality of the family environment of children with better performance in the Denver II Screening Test, compared to children with developmental delays, these data are observed in Table 4.

It was observed that some socio-environmental variables influence the quality of the environment. Children living in households without water treatment presented worse levels of family environment quality, as well as those with worse socioeconomic levels (Table 5). When comparative analysis was carried out, it was also analyzed that the variables availability of electric energy $(p<0.01 *)$ and characteristics of the private bathroom type $(\mathrm{p}<0.01 *)$ had a positive influence on the quality of the family environment, once that children who have them have significantly higher homes to stimulate neuropsychomotor development.

Table 3: Qualitative characteristics of the child for developmental variables according to the Denver II protocol.

\begin{tabular}{lccccc}
\hline Variable & \multicolumn{3}{c}{ Description } & $\mathbf{X}^{\mathbf{2}}$ & $\mathbf{p}$ \\
\hline & Normal & Risk & Delay & & \\
Personal-Social & $45(90.0 \%)$ & $4(8.0 \%)$ & $1(2.0 \%)$ & & \\
Fine motor & $45(90.0 \%)$ & $5(10.0 \%)$ & - & 32.00 & $<\mathbf{0 . 0 1}^{*}$ \\
Language & $35(70.0 \%)$ & $3(6.0 \%)$ & $12(24.0 \%)$ & 32.68 & $<\mathbf{0 . 0 1}^{*}$ \\
Thick Motor & $50(100.0 \%)$ & - & - & - & - \\
General index & $34(68.0 \%)$ & $3(6.0 \%)$ & $13(26.0 \%)$ & 30.04 & $<\mathbf{0 1 . 0 1}^{*}$ \\
\hline
\end{tabular}

Table 4: Comparative analysis (ANOVA one way) of the factors of the quality of the family environment according to the HOME protocol, regarding the profile factor of neuropsychomotor development of Denver II.

\begin{tabular}{lccccc}
\hline Variable & Normal & Risk & Delay & f & p \\
\hline Responsiveness & $8.97 \pm 2.42$ & $8.00 \pm 1.00$ & $5.46 \pm 2.63$ & 9.78 & $<\mathbf{0 . 0 1}^{*}$ \\
Acceptance & $5.68 \pm 0.73$ & $5.33 \pm 0.58$ & $4.62 \pm 2.18$ & 3.31 & $\mathbf{0 . 0 5}^{*}$ \\
Organization & $4.53 \pm 1.80$ & $3.33 \pm 0.58$ & $3.31 \pm 1.18$ & 3.06 & 0.06 \\
Material & $4.47 \pm 2.81$ & $2.67 \pm 1.53$ & $2.23 \pm 0.93$ & 4.36 & $\mathbf{0 . 0 2}^{*}$ \\
Involvement & $4.18 \pm 1.59$ & $2.00 \pm 0.00$ & $2.54 \pm 0.52$ & 9.17 & $<\mathbf{0 . 0 1}^{*}$ \\
Variety & $3.65 \pm 1.01$ & $3.33 \pm 0.58$ & $2.62 \pm 0.77$ & 5.67 & $\mathbf{0 . 0 1}^{*}$ \\
Total Score & $31.47 \pm 8.06$ & $24.67 \pm 2.52$ & $20.77 \pm 4.68$ & 10.87 & $<\mathbf{0 . 0 1 ^ { * }}$ \\
\hline
\end{tabular}


Table 5: Comparative analysis (one-way ANOVA) of the quality of the family environment according to the total score by the Home protocol, related to socio-environmental variables

\begin{tabular}{|c|c|c|c|c|c|c|c|c|}
\hline \multirow{2}{*}{$\begin{array}{l}\text { Variable } \\
\text { Economic class }\end{array}$} & \multicolumn{6}{|c|}{ HOME/ Description } & \multirow{2}{*}{$\begin{array}{c}\mathbf{f} \\
13.76\end{array}$} & \multirow{2}{*}{$\frac{p}{0.01^{*}}$} \\
\hline & B & $\mathrm{C}$ & $\mathrm{D}$ & & $E$ & & & \\
\hline & $40.50 \pm 4.95$ & $43.20 \pm 2.05$ & $28.40 \pm 7.83$ & & $25.66 \pm 6.53$ & & & \\
\hline \multirow[t]{2}{*}{ Father abandonment } & Total & No & Death & & & & 0.89 & 0.42 \\
\hline & $23.60 \pm 3.78$ & $28.86 \pm 8.83$ & 26.00 & & & & & \\
\hline \multirow[t]{2}{*}{ Family strutucture } & Mono & Mono Ext. & $\mathrm{Bi}$ & & Bi Ext. & & 0.72 & 0.55 \\
\hline & 24.00 & $24.00 \pm 3.94$ & $28.27 \pm 9.33$ & & $30.14 \pm 7.81$ & & & \\
\hline \multirow[t]{2}{*}{ Number of siblings } & 0 & 1 & 2 & 3 & 6 & 7 & 0.88 & 0.53 \\
\hline & $28.17 \pm 9.07$ & $30.75 \pm 9.9$ & $21.00 \pm 4.58$ & 28.0 & $39.0 \quad 18.0$ & 24.00 & & \\
\hline \multirow[t]{2}{*}{ Water treatament } & Filtration & Boil & Chlorination & & Without & & 10.96 & $<0.01^{*}$ \\
\hline & $40.29 \pm 7.27$ & $29.25 \pm 6.95$ & $29.50 \pm 7.38$ & & $24.08 \pm 6.10$ & & & \\
\hline
\end{tabular}

\section{DISCUSSION}

In the last ten years, the Brazilian economy was marked by a combination of economic growth and improved income distribution. The Brazilian gross domestic product per capita increased by $29 \%$ and was characterized by a more favorable evolution of the income of the most impoverished population, contributing to the reduction of inequalities. In 2001, 14.0\% of the Brazilian population had a per capita household income of up to the US \$ $1.25 /$ day, an international extreme poverty line. Eleven years later, in 2012, extreme poverty had been reduced to $3.5 \%$ of the population ${ }^{16}$.

Families living in poverty live with more unstable living conditions than those with better socioeconomic resources, thus limiting investments in resources and materials that promote an exciting daily life for their children. As well as the organization of routines, games, readings, interactive games, among other activities that reinforce children's development ${ }^{7,17,18}$.

The results of the present research indicate that the worse the quality of the family stimulation available to the child, the more affected will be its neuropsychomotor development. This finding was mainly due to the lower supply of "learning materials" and "organization of the environment".

These results are in agreement with other Brazilian studies that used the HOME in the context of economically disadvantaged families: a study with 147 children between 24 and 36 months of age in the microregion of the Alto Vale do Jequitinhonha, observed that the family environment had a direct impact, and significant in children's cognitive development, more than half of the children (66.7\%) lived in high-risk homes, and the most affected domain was "learning material" $(60.5 \%)^{19}$.

Lamy et al. $^{20}$ studied 176 children in the same age group in a community in the periphery of São Luis (MA), to verify the relationship between home stimuli and child development. They found that a little more than half of the home environments presented a high risk, with "learning materials" being the subscale with the highest percentage of committed residences $(73.9 \%)$, followed by "organization of the environment" (64.2\%).

In riverine communities, the links are intense among children and the family environment, as families spend more time in the home than in other places. In this way, the domestic environment becomes essential for the development of infants, who grasp motor and social skills that will be improved and used throughout life ${ }^{21}$.

The present study also observed a significant relationship of some environmental factors with a high level of risk of family stimulus quality in the community of riverine children: the worst economic class, the lack of water treatment, the absence of electric power and the bathroom of the external type.

A survey of 239 children between 3 and 18 months of the municipality of Juiz de Fora (MG), showed a significant impact on the quality of the home environment and socioeconomic risk factors. The economic level of the parents seems to be related to the greater access to information and, consequently, greater knowledge about the mechanisms that can generate adequate development and stimulating environment for the children, regardless of the age of the child ${ }^{22}$.

González et $a .^{23}$ analyzed the quality of the home environment of 1,031 urban children between 0 and 3 years old in Mexico City. They found that the lower socioeconomic status had a significant influence $(p<0.0001)$ on both the general and all the subscales of HOME, demonstrating that the quality of the family environment stimulus is also sensitive in children from North America, Mexico.

A study in South Asia, Pakistan, surveyed 1,219 children aged 0-3 years old from the urban and rural sectors. With the use of the HOME scale, they observed that children in the rural sector presented the quality of the family environment inferior to those of the urban sector. However, there was no significant correlation between socioeconomic status and housing conditions, only with neuropsychomotor development ${ }^{24}$.

Housing conditions usually portray the socioeconomic difficulties of families. Children who live in houses that do not have adequate water or toilet service have their development affected because they are more exposed to diseases that lead to mental and physical difficulties ${ }^{25}$.

Regarding child development, it is observed that the significant majority of the riverside children presented normal neuropsychomotor development. The gross motor area, even, showed no deviation, whereas, among the 
children in the delayed range, the area most affected was that of language, almost in its entirety.

Lima et al. ${ }^{26}$ evaluated the neuropsychomotor development, with the Denver II Screening Test, 22 institutionalized children between 0 and 4 years old, living in Recife (PE), and found that the main area detected with delay was language (59.1\%), and the least affected was the gross motor area $(18.2 \%)$.

Lourenço ${ }^{27}$ carried out a study focused on the Amazonian reality, evaluated gross motor development by the Denver II Screening Test of 188 children from 0 to 24 months of age, being the sample of 85 riverine and 103 urban children. As a result, it was observed that the significant majority of the children developed in a healthy way $(89.9 \%)$, and the motor development occurs in the majority of the same age group for both populations, but the riverside ones are in disadvantages when they considered health and housing conditions.

Already another study in Amazonian communities, evaluated the neuropsychomotor development, also with Denver II Screening Test, of 37 riverine children between 24 and 36 months of age. It was found that a significant majority of samples were considered normal (51.4\%), followed by risk $(29.7 \%)$, and in less proportion with delay $(18.9 \%)$. The main areas of delay were found in language and gross motor, together $(57.2 \%)^{28}$.

The environment that characterizes the Amazonian context, such as rivers and vast forests, where several games are played within the routine of riverine children, propitiate the improvement of motor skills and result in the creation of new behavioral resources. As they acquire greater independence and autonomy from the various environmental stimuli, in addition to the proximity of children with their caregivers, they potentiate child development and socialization with the community ${ }^{21}$.

On the other hand, the development of the language area is particularly susceptible to the harmful effects of living in homes with low socioeconomic resources of children in the first years of life, associated to the parents' low level of education. In addition to language, impairment of executive, emotional and cognitive functions still occurs ${ }^{8,29,30}$.

The present study observed that environmental factors were not significant for the neuropsychomotor development of the riverside children of the Amazonian community Panacauera, since most of them presented without delay in development. Among the minority of children classified as late, the language field was detected as the main affected area.
However, of the children detected with some delay or risk in development, the variable with the most significant impact was the quality of stimulation of the family environment, which, in turn, suffered a significant influence of the socioeconomic and housing conditions that infants live. In this way, evaluating the quality of the family environment for the development of children within riverine families in communities of extreme poverty, can provide essential elements for health and education policies to be programmed by public entities in communities of the Amazon region, in order to awareness of the importance of assessing and educating children in these risk areas.

There are few researches with riverine children living in the Amazon region, and few longitudinal studies are described in the literature, which in a way makes contextualization difficult. The Amazonian biodiversity, its rivers, boreholes and igapós with community that borders the rivers made difficult the physical access to the community, since the only means of transport used is fluvial, with restricted days and hours for the displacement of the municipality of Igarapé-Miri to the community, which limited the locomotion of the researchers and the number of the sample. It is suggested the reproduction of the study in other Amazonian communities, to verify the existence of the same pattern of results, and to increase the knowledge of the correlation of environmental factors with the development of riverine children.

\section{CONCLUSION}

The present study found that the influence of environmental factors was not significant concerning the neuropsychomotor development of the riverside children of the Amazonian community Panacauera, since most of them presented without developmental delay. Among the minority of children classified as late, the language field was detected as the main affected area.

The variable with the most significant impact on development was the quality of stimulation of the family environment, which, in turn, suffered a significant influence of the socioeconomic conditions and housing that the infants live in there. In this way, evaluating the available stimulation for children within riverine families in communities of extreme poverty can provide essential elements for health and education policies to be programmed by public entities.

\section{REFERENCES}

1. Silva SSC, Santos TM, Pontes FAR, Maluschke JB. Avaliação de famílias Ribeirinhas: uma proposta adaptada ao contexto. Rev Interinstitucional Psicol. 2011;4(2):253-63.

2. Silva SSC, Pontes FAR, Santos TM, Maluschke JB, Mendes LSA, Reis CD, et al. Rotinas familiares de Ribeirinhos Amazônicos: uma possibilidade de investigação. Psicol Teor Pesq. 2010;26(2):341-50.

3. Walker SP, Chang SM, Vera-Hernández M, Grantham-McGregor S. Early childhood stimulation benefits adult competence and reduces violent. Pediatrics. 2011;127(5):849-57.

4. Delvan JS, Becker APS, Braun K. Fatores de risco no desenvolvimento de crianças e a Resiliência: um estudo teórico. Rev Psicol IMED. 2010;2(1):349-57. DOI: https://doi.org/10.18256/2175-5027/psico-imed.v2n1p349-357 
5. Santos LM, Santos DN, Bastos ACS, Assis AMO, Prado MS, Barreto ML. Determinants of early cognitive development: hierarchical analysis of a longitudinal study. Cad Saúde Pública. 2008;24(2):427-37. DOI: http://dx.doi.org/10.1590/S0102-311X2008000200022

6. Dessen MA, Polonia AC. A família e a escola como contextos de desenvolvimento humano. Paidéia. 2007;17(36):21-32. DOI: http://dx.doi.org/10.1590/S0103-863X2007000100003

7. Kenney MK. Child, family, and neighborhood associations with parent and peer interactive play during early childhood. Matern Child Health J. 2012;16(Suppl.1):S88-101. DOI: http://dx.doi.org/10.1007/s10995-012-0998-7

8. Fernald LCH, Kariger P, Hidrobo M, Gertler PJ. Socioeconomic gradients in child development in very young children: Evidence from India, Indonesia, Peru, and Senegal. PNAS. 2012;109(Suppl. 2):1727380. DOI: https://dx.doi.org/10.1073/pnas.1121241109

9. Fundo das Nações Unidas para a Infância (UNICEF - Brasil). Situação Mundial da Infância 2013: crianças com deficiência. [cited 2014 Jan 16] Available from: http://www.unicef.org/brazil/pt/PT_SOWC2013.pdf.

10. Programa das Nações Unidas para o Desenvolvimento (PNUD). Ranking do IDH dos estados. [cited 2014 Feb 16] Available from: http://www.pnud.org.br/atlas/ranking/Ranking-IDHM-Municipios-2010.aspx. 11.

11. Brasil. Instituto Brasileiro de Geografia e Estatística (IBGE). Informações Estatísticas. Pará, Igarapé Miri, 2013. [cited 2014 Jan 16] Available from: http://cod.ibge.gov.br/236w1.

12. Associação Brasileira de Empresas de Pesquisa (ABEP). Critério de classificação econômica Brasil, 2008. [cited 2014 Jan 16] Available from: http://www.abep.org/criterio-brasil.

13. Caldwell BM, Bradley RH. Administration manual HOME observation for measurement of the enviroment. Arkansas: University of Arkansas at Little Rock, 1984.

14. Totsika V, Sylva K. The home observation for measurement of the environment revisited. Child Adolesc Mental Health. 2004;9(1):25-35. DOI: https://dx.doi.org/10.1046/j.1475-357X.2003.00073.x

15. Frankenburg WK, Dodds J, Archer P, Shapiro H, Bresnick B. The Denver II: a major revision and restandardization of the Denver Developmental Screening Test. Pediatrics. 1992;89(1):91-7.

16. Programa das Nações Unidas para o Desenvolvimento (PNUD). Indicadores de desenvolvimento brasileiro 2001-2012. [cited 2014 Oct 14] Available from: http://aplicacoes.mds.gov.br/sagirmps/ ferramentas/docs/IDB-portugues-final.pdf.

17. Milteer RM, Ginsburg KR. The Importance of play in promoting healthy child development and maintaining strong parent-child bond: focus on children in poverty. Pediatrics. 2012;129(1):204-13.

18. Duncan GJ, Ziol-Guest KM, Kalil A. Early-Childhood poverty and adult attainment, behavior, and health. Child Dev. 2010;81(1):306-25. DOI: https://dx.doi.org/10.1111/j.1467-8624.2009.01396.x

19. Morais RLS, Carvalho AM. Desenvolvimento cognitivo e motor de crianças nos primeiros anos de vida e qualidade do contexto ambiental: uma análise relacional. Tese (Doutorado) - Universidade Federal de Minas Gerais. Belo Horizonte: 2013.

20. Lamy Filho F, Medeiros SM, Lamy ZC, Moreira MEL. Ambiente domiciliar e alterações do desenvolvimento em crianças de comunidade da periferia de São Luís - MA. Ciênc Saúde Coletiva. 2011;16(10):4181-7. DOI: http://dx.doi.org/10.1590/S1413-81232011001100023

21. Silva DG, Pontes FAR, Silva SSC. Relações familiares de duas crianças ribeirinhas da Amazônia. Psicol Teor Prát. 2011;13(3):139-51

22. Defilipo EC, Frônio JS, Teixeira MTB, Leite ICG, Bastos, RR, Vieira MT, et al. Oportunidades do ambiente domiciliar para o desenvolvimento motor. Rev Saúde Pública. 2012;46(4):633-41. DOI: http://dx.doi.org/10.1590/S0034-89102012005000040

23. González RR, Olea MF, Limón KMS, Sánchez C, Rosas HA. Experiencia de la aplicación y critérios para la interpretación de dos versiones del Inventario HOME para infantes de 0 a 3 años de vida. Salud Mental. 2010;33(1):57-66.

24. Avan BI, Raza AS, Kirkwood BR. A community-based study of early childhood sensory stimulation in home environment associated with growth and psychomotor development in Pakistan. Int J Public. 2014;59(5):779-88. DOI: http://dx.doi.org/10.1007/s00038-013-0525-7

25. Instituto Brasileiro de Geografia e Estatística (IBGE). Síntese de indicadores sociais uma análise das condições de vida da população brasileira. 2013. [cited 2014 Oct 14] Available from: https://biblioteca. ibge.gov.br/visualizacao/livros/liv66777.pdf.

26. Lima AKP, Lima AO. Perfil do desenvolvimento neuropsicomotor e aspectos familiares de crianças instucionalizadas na cidade do Recife. Rev CES Psicol. 2012;5(1):11-25. 
27. Lourenço JMQ, Gusmão SRB. O desenvolvimento motor da criança urbana e ribeirinha do município de Belém - Pará na faixa etária de 0 a 1 ano. Dissertação (Mestrado) - Universidade do Estado do Pará. Belém: 2004.

28. Guerreiro TBF, Hashimoto AS. Desenvolvimento de crianças Ribeirinhas das Ilhas ao Sul de Belém Pará. Monografia (Conclusão de Curso) - Universidade do Estado do Pará. Belém: 2007.

29. Hanson JL, Chandra A, Wolfe BL, Pollak SD. Association between income and the hippocampus. PLoS One. 2011;6(5):e18712. DOI: https://dx.doi.org/10.1371/journal.pone.0018712

30. Raizada RDS, Kishiyama MM. Effects of socioeconomic status on brain development, and how cognitive neuroscience may contribute to levelling the playing field. Front Hum Neurosci. 2010;4:3. DOI: https://dx.doi.org/10.3389/neuro.09.003.2010

\section{Resumo}

Introdução: É Os primeiros anos da vida de uma criança são marcados por um importante desenvolvimento, além da alta sensibilidade às influências ambientais, como condições de pobreza e moradia e qualidade e estrutura familiar. Desta forma, a identificação de fatores de riscos ambientais e atrasos do desenvolvimento neuropsicomotor, somada a intervenção precoce, são essenciais para um desenvolvimento saudável.

Objetivo: Analisar o efeito dos fatores ambientais no desenvolvimento neuropsicomotor de crianças em comunidade Amazônica.

Método: Estudo quali-quantitativo do tipo transversal e analítico, realizado com 50 crianças entre 24 e 36 meses de idade, de ambos os sexos, residindo em uma comunidade Amazônica. Foram utilizados um questionário socioeconômico-ambiental, o Infant/Toddler (IT) HOME Inventory, para analisar a qualidade do ambiente familiar e o Teste de Triagem de Denver II, para triagem do desenvolvimento neuropsicomotor, e a análise descritiva dos dados foi feita utilizando o cálculo das médias e desvios padrão.

Resultados: O estudo constatou que a maioria significativa das crianças apresentou 0 desenvolvimento neuropsicomotor normal, no entanto, das crianças classificadas com atraso, a variável de maior impacto no desenvolvimento foi a qualidade do ambiente familiar, que por sua vez sofreu influência da classe econômica inferior, falta de tratamento da água, ausência de energia elétrica e banheiro tipo externo.

Conclusão: Os fatores ambientais não foram significativos perante o desenvolvimento neuropsicomotor das crianças ribeirinhas da comunidade amazônica.

Palavras-chave: desenvolvimento neuropsicomotor, meio ambiente, relações familiares, vulnerabilidade social.

${ }^{0}$ The authors (2018), this article is distributed under the terms of the Creative Commons Attribution 4.0 International License (http:// creativecommons.org/licenses/by/4.0/), which permits unrestricted use, distribution, and reproduction in any medium, provided you give appropriate credit to the original author(s) and the source, provide a link to the Creative Commons license, and indicate if changes were made. The Creative Commons Public Domain Dedication waiver (http://creativecommons.org/publicdomain/zero/ $1.0 /)$ applies to the data made available in this article, unless otherwise stated. 